\title{
Translating Figurative Language
}

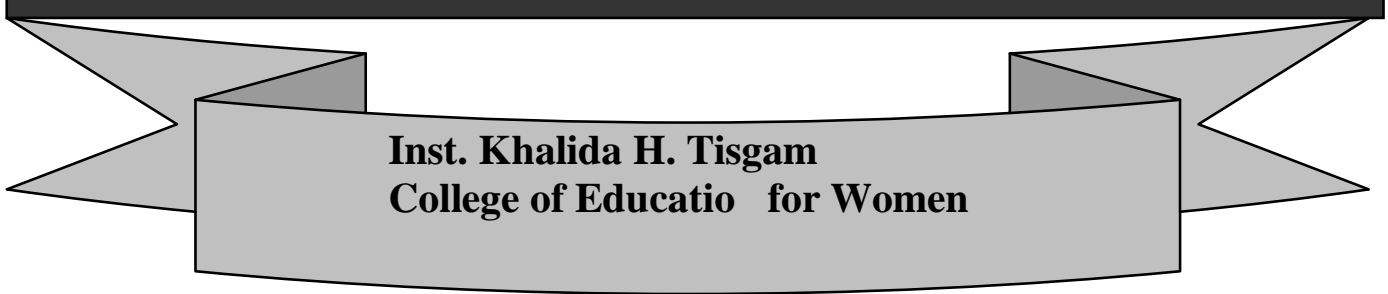

\begin{abstract}
We are living in a continuously changing world in which people use different languages to communicate successfully. But this communication is not always successful because many users of language use different means of expression. They, sometimes, use a literal meaning for what they really intend, other times they use language vaguely in a way that needs a sort of clarification, especially when the language is used figuratively. This clarification is achieved through translation.

The aim of this paper is to shed some light on certain cases in which English figurative expressions have been translated literally into Arabic, depending on a famous recommendation in translation theory saying that figurative language should never be translated literally because such kind of translation is perceived as the worst possible translation technique. It also studies some excerpts of an English short story; The Happy Prince by Oscar Wilde, by analyzing their language and finding out how they were rendered as well as showing the translators' choices when translating the same SL text and how the lack of a semantic and literary knowledge leads to a poor translation.
\end{abstract}




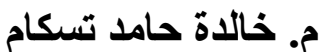
كلية التربية للبنات قسم اللغة الإنكليزية اللينات

نحن نعيش في عالم يتغير باستمرار يستعمل فيه الناس لغات مختلفة ليتواصلوا بنجاح إلا أن هذا

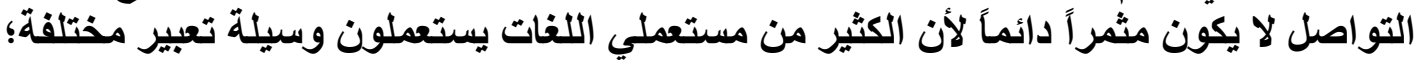

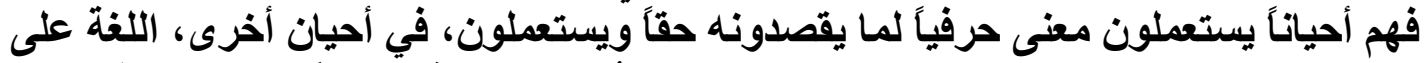

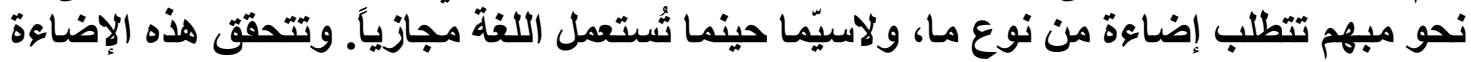

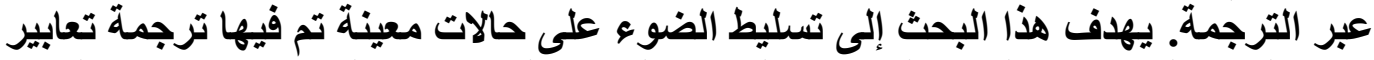

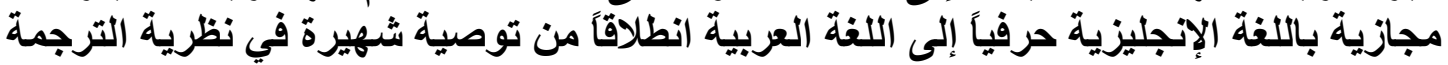

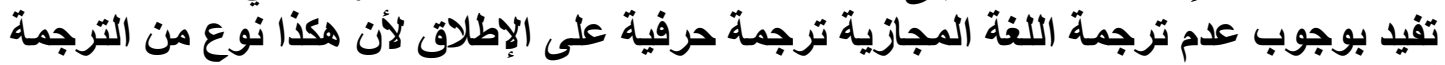

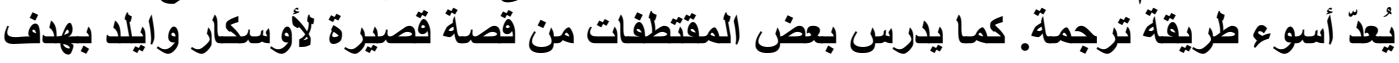

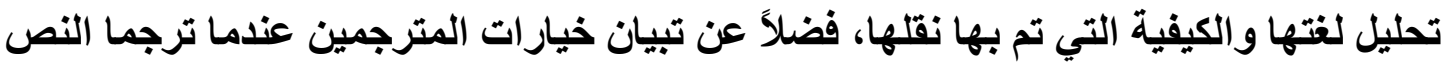
الأصل نفسه والكيفية التي يؤدي بهي بها الافتقار للمعرفة الدلالية إلى ترجمة فيان سيئة.

\section{Introduction}

One cannot be exaggerating when saying that translation is as old as language itself because if there is no language, there will not be translation. Newmark (1981: 3) asserts that the first marks of translation can be traced back to as far as $3000 \mathrm{BC}$.

Figurative language is a brilliant means by which writers express their style, build their ideas and create a meaningful flavor in their writing. It is worth noting that Katz (1996: 18) stresses that "an utterance can be understood as figurative when the expressed meaning differs from the meaning one intends to convey."

Translating figurative language is considered a hard task. It is not an easy job at all, particularly if there is no equivalent in TL (LewandowskaTomaszczyk et al., 2010: 368)

Newmark (1998: 103) mentions five main features of figurative language which should be rendered by the translator: (1) figurativeness and allegory; (2) onomatopoeic nature (that sound is as important as meaning); (3) rhythm; (4) each word counts; and (5) full of polysemous words and collocations.

Basically, figurative language is the language that has more than one meaning. It is a language which does not convey a real (or literal) meaning and is transferred from the real meaning to a figurative one by using an 
implicit or indirect meaning in a way that requires analyzing the text to reach at the intended meaning (Kennedy, 2002:119).

It is a sort of language that uses images and represents things in an exaggerated way (Kennedy, 1983: 479). It includes many tropes, such as: allusion, hyperbole, antithesis, repetition, metaphor, simile, personification, apostrophe, climax, irony, litotes, metonymy, paradox, pleonasm, euphemism, onomatopoeia and synecdoche (Keraf, 1998: 129).

The translation of such kind of language is a very hazardous job. Translators, as Rojo (2009: 22), "usually dream of achieving an ideal replica of the source text, but in practice they often have to accept that not everything can be translated exactly into different language."

Any translator cannot render any figurative expression literally because if s/he does so, the result will be misinterpretation. He/she has to scan and analyze the figurative text meticulously in order to arrive at the correct translation (Larson, 1998:275).

In the present paper, two Arabic translations of Oscar Wilde's story, 'The Happy Prince', are assessed in a way to show the difficulty of translating figurative language. The result could be that different translation methods could lead to different translated versions of the same text. Besides, it is meant to be a means for rejecting the literal translation as being the main source behind destroying the original text.

One can add that cultural and stylistic differences between the source language (henceforth SL) and the target language (henceforth TL) texts may lead to a mistaken translation because such kind of differences might lead the translators to change the meaning of the SL text in order to be in line with the translated text. This might be caused by the translator who may follow the said meaning (i.e., the literal meaning) instead of pursuing the intended meaning (i.e., the figurative one).

\section{What Is Translation?}

Nowadays, translation has become a field that needs a thorough study because of the recurrent changes in the world. It is one of the best means to build bridges of communication among peoples. It exits, as Steiner (1975: 49) refers, "because men speak different languages". 
Nida (1964: 161) mentions that there are many definitions of translation to the extent that:

Definitions of proper translating are almost as numerous and varied as the persons who have undertaken to discuss the subject. This diversity is in a sense quite understandable; for there are vast differences in the materials translated, in the purpose of the publication, and in the needs of the prospective audience.

Catford (1965: 20) defines translation, as "an act of transference, in which a text from the source language is replaced by its equivalent in the target language".

Hopkins (1976: 141) argues that when people do not speak or read a foreign language they hold false attitudes towards translation. They think in the following way:

Translating is to a printed foreign-language text what paleography is to Medieval Latin manuscripts. The paleographer learns how to interpret symbols. For example, - stands for "est"; "dr" stands for "dicitur." Although these abbreviations vary from one writer to the next, when a paleographer masters a scribe's shorthand, he can accurately transcribe the latter's manuscripts into longhand. Similarly, if a translator has mastered a list of correlated words (e.g., "das Pferd" = "the horse"; "der Baum" = "the tree"), he can accurately translate the text into his native language.

Newmark (1988: 4) stresses that:

The translator has to have flair and a feel for his own language. There is nothing mystical about this "sixth sense", but it is compounded of intelligence, sensitivity and intuition, as well as of knowledge. This sixth sense, which often comes into play during a final revision, tells you when to translate literally, and also, instinctively, perhaps once in a hundred or three hundred words, when to break all the rules of translation. 
Brislin (1976: 1) notes that:

The general term referring to the transfer of thoughts and ideas from one language (source) to another (target), whether the languages are in written or oral form; whether the languages have established orthographies or do not have such standardization or whether one or both languages is based on signs, as with sign languages of the deaf.

Catford (1978:1) adds that translation is a process on language by subtitling a text in one language with a text in another. He argues that what is transferred between these two languages is not meaning, but replacing an SL meaning by TL meaning.

Nida (1984:83) points out that translation consists of reproducing the closest natural equivalent of the source language message in the receptor language, by concentrating first on meaning and then on style.

Lörscher (1991: 1) argues that the ever increasing information in different economic, political and scientific levels is the main cause behind the urgent need for translation to achieve communication between different languages and cultures.

One can notice that these definitions of translation are compatible with each other. In addition, many other theorists define translation in a rather similar way. What is most important to concentrate on is the transfer of meaning from one language into another and the accuracy of this transfer.

But one may ask here, what make a translation good? Definitely, there are many requirements among which what Blanchot (1990: 83) refers as:

It is the one which does not read like translation, or one marvels at just how identical it is with its original, how it is truly one and the same work; but in the first case one effaces the origin of the work to the advantage of the new language, and in the second case, one effaces the originality of either language to the advantage of the work; in both cases, something essential gets lost.

What Is Meaning? 
As it is shown in the definitions of translation, meaning is the cornerstone of the process of translation. It is therefore necessary to shed some light on it.

The search for meaning is not always an easy job. (Chesterman, 1989: 134) stresses that "meaning is a complicated, many-levelled, a network of relations".

Words have different meanings according to the context. Hanks (1987: 127) mentions different sets of words, as in the case of bank, with its senses 'slope of land alongside a river' and 'financial institution'. He stresses that:

On the one hand, bank co-occurs with words and expressions such as money, notes, loan, account, investment, clerk, official, manager, robbery, vaults, working in, its actions, First National, of England, and so forth. On the other hand, we find bank co-occurring with river, swim, boat, east (and of course West and South, which have acquired special meanings of their own), on top of the, and of the Rhine.

Larson (1984: 36) argues that the objective of translation is to transfer the meaning of a text in one language into another one, on the condition that the translator must know that there are different types of meanings before s/he attempts to tackle the text.

As for Cruse (1986: 16), he observes that the linguistic meaning of a word is formed from the meanings of other words and how the context affects the meaning.

We can picture the meaning of a word as a pattern of (dis)affinities with all the other words in the language with which it is capable of contrasting semantic relations in grammatical contexts.

But there is another type of meaning called figurative meaning.

Nida and Taber (1969: 87) stress that each word has a certain principal meaning, but some words may also have figurative meanings which are very different from the principal meanings in their culture and language atmosphere. Accordingly, the translator must try to decipher the word to look for the figurative meaning. That is why Bell (1991: 83) says 
that the most important problem in translation is caused by the fact that "the relationships of similarity and difference between concepts and the words that express them do not always necessarily coincide in the languages involved in the translation."

\section{Literal Meaning and Figurative Meaning}

Oxford American Dictionary (1980: 386) defines the word 'literal' as being "in accordance with the principal meaning of a word or the actual words of a phrase, as contrasted with a metaphorical (figurative) or exaggerated meaning." Hence, it is possible to conclude that the literal meaning of any phrase or any sentence is the meaning that does not surpasses the principal meanings of the phrase or sentence.

Glucksberg (2001: 8) distinguishes literal from figurative meanings. He refers to the figurative meaning as the metaphorical meaning by saying that:

1. Literal meaning is basic and has unconditional priority. It does not cause problems and is not confined to a certain context. In other words, the literal meanings of expressions will not be changed, no matter of context.

2. Figurative meaning is derived from the literal meaning and can be detected by knowing the nature of the substitution of the tropical for the literal.

3. Accordingly, the figurative understanding is much more complex and demands more cognitive work than the literal one.

Glucksberg (ibid: 10) advises of the following rules to deal with a figurative meaning:

* Derive the literal meaning of an utterance.

*Compare the derived literal meaning with the context of the utterance.

*If the literal meaning makes sense, adopt that meaning as the intended meaning. If it does not make any sense, then you have to look for an alternative, nonliteral meaning that does make sense in the context.

To explain it well enough, Glucksberg (ibid: 12) mentions the following examples for the word 'open' and how it is used literally or figuratively:

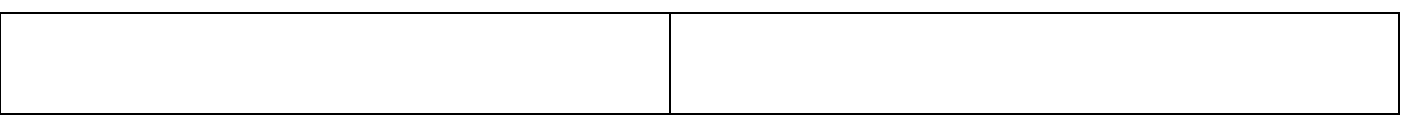




\begin{tabular}{|c|c|}
\hline 1. He opened the door. & 1. فتح الباب. \\
\hline $\begin{array}{l}\text { 2. The surgeon opened the } \\
\text { patient's chest. }\end{array}$ & 2. شق الجراح صدر المريض. \\
\hline 3. He opened his eyes. & 3. فتح عيناه. \\
\hline 4. She has an open mind. & 4. لها ذهن متقد. \\
\hline 5. She opened Pandora's box. & 5. جرّت على نفسها الويلات. \\
\hline $\begin{array}{l}\text { 6. He opened her eyes to her } \\
\text { husband's infidelities. }\end{array}$ & 6. كثف لها عن خيانات زوجها. \\
\hline
\end{tabular}

Moreover, to show the importance of figurative language, it is possible to quote Ullmann (1962: 34) saying that "a language without metaphor and metonymy is inconceivable: these two forces are inherent in the basic structure of human speech."

Vitez (1996: 45) describes the importance of figurative meaning in translation by saying that:

During the translating from one language to another, the danger of flattening out meaning is heightened: the translator dares not take the kind of liberties that the author takes with his language; he is afraid of appearing stupid, or being perceived as a mediocre writer. Therefore, more or less consciously, he translates with detachment; the apparent meaning is the same, however, the style is weakened: I should say that he undertranslates.

Reimer (1994:11) says that "we will need to learn much more than we presently understand about the ways knowing about and knowing why affect knowing within and how".

\section{Characteristics of Figurative Language}

Figurative language is a kind of language that does not employ the literal aspect of language. When a writer uses a figurative language, it 
means that the writer is using the language creatively in a way that makes any one able to discern his/her style obviously (Reaske, 1966: 33).

Lewandowska-Tomaszczyk et al. (2010: 135) states that figurative language

Does not to be understood as only metaphor (or simile), but also all those occurrences of language which make the language user sit up and become very alert, not because the occurrences of language that he reads or hears are interesting, unexpected, funny, difficult to interpret or not true, etc., or because they do not fit in with the rest of the discourse in question because of a difference in style, person, tenor, register, and/or other text linguistic features, but because they interrupt his usual "flow" of reading or listening, that is because he cannot figure out as quickly and efficiently as usual what they mean, not even after some time of using dictionaries or other references, although the actual forms taken individually are quite standard and well-known to him; the only thing is that, when interrupted literally as usual, their contribution does not seem to make much sense. In other words, figurative language is that type of language that interrupts the "flow" of translating because the translator stops many times trying to decipher the meaning.

Besides, they (ibid.: 371) assert that figurative language appears at the semantic and cognitive levels. Meaning components between lexical items in different semantic fields are transferred at the semantic level. While at the cognitive level, figurative language is considered as a reflection of different concepts to form new concepts. Recanati, (2004: 3) asserts that semantics deals with the question of literal meaning. The content of an expression is determined by the interpreter by depending on the context. Accordingly, the literal content of a complete expression is "what is said".

Perrine (1982: 39) stresses that there are many reasons behind the importance of this language, among which are the following: 
First, it supplies readers with imaginative pleasure of literary works.

Second, it injects writing with additional imagery in a way that turns the abstract into concrete, as well as adding more flavor to literary works to make them more sensuous.

Third, it is a means for emotionalize the ordinary informative statements.

Fourth, it is a rhetorical means for saying many things in brief.

\section{The Importance of Literature}

Since the figurative language is widely used in literature, it is better to shed some light on literature. The word 'literature' is derived from the Latin word 'littera', meaning 'letter' (Bressler,1998:6). According to Ghazala (2014:9), there are certain requirements which are necessary for the literariness in literature in particular:

(a) The possibility of reading literature at more than one level.

(b) Symbolism. There are many brilliant literary works which are symbolic to depict reality behind the figurative aspects.

(c) The emotive aspects of emotions and feelings.

Accordingly, Adams (1973:11) asserts that the translation of literary works is much harder than their composition because

The original composition is the art of choosing the exactly right word or expression, and includes the option of changing and modification as deemed appropriate whereas the art of literary translation is the art of choosing among a set of possible compromises.

\section{Suggestions to Translate Figurative Language}

The difficulty of translating figurative Language lies in the fact that figurative Language is not only mere words but conceptual systems. Accordingly, the process of translation does not involve only a transfer from one language to another, but also a transfer from one way of conceptualizing the world into another (Lewandowska-Tomaszczyket al.(2010: 374).

Adams (1973: 113) suggests that there are three ways to translate figurative Language:

1. It is possible to translate the sense of the word non-figuratively. In other words, one can make the intended meaning as plain as possible so that there is no longer a figurative sense in the translated text (The TL).

E.g. "The Kettle is boiling"---------"The water is boiling" 
2. It is possible to keep the original word, but add the sense of the word.

E.g. "The government wanted to reintroduce the electric chair"-----

"The government wanted to reintroduce the execution by using the electric chair."

3. One can substitute a figurative expression of the receptor language for the figurative expression of the source language: in one language, tongue may be used with a figurative meaning of "speech," in another language lips may have this figurative sense.

Larson (ibid: 254) argues that such expressions can be translated in one of the following ways:

1. If it sounds natural and is understood correctly by the reader, then it can be kept in the target language.

2. It can be rendered as a simile by adding 'like' or 'as'

3. It is possible to use a metaphor of the target language which has the same meaning.

4. It can be kept but the meaning should be explained.

5. Its meaning can be translated without keeping the metaphorical imagery.

Thelen (1990: 294) asserts that the translator of figurative language must have a talent for creative writing because such kind of language conveys meaning in a very economical and creative way, and gives some suggestions to the translators of figurative expressions:

\section{STEP 1}

1. Look up the problem words in a sentence with a figurative expression in various dictionaries.

2. Try to impose lexical-system-like structures on the appropriate definitions of these problem words as given by these dictionaries.

3. Try to impose lexical-system-like structures on the whole actual sentence in the SL text.

4. Compare- problem word by problem word- lexical-system-like structure of the various problem words in isolation with that of the problem words in the context of the whole actual sentence.

\section{STEP 2}


1. Look up the problem words in a sentence with a figurative expression in various dictionaries.

2. Try to impose lexical-system-like structures on the appropriate definitions of these problem words as given by these dictionaries.

3 . Think of as many situations as possible that you may have experienced with what the problem words refer to in reality.

4. Try to impose lexical-system-like structures on these situations.

5. Try to impose lexical-system-like structures on the whole actual sentence in the SLT.

6. Compare- problem word by problem word- the lexical-system-like structure of the various problem words in isolation in (2) and (4) with that of the problem words in the actual context of the whole actual sentence.

\section{STEP 3}

1. Decide whether the instance of figurative language is important in the wider context of the text to be translated.

2. If it is, then translate it by figurative language as well, preferably by its most direct equivalent in the target language.

3. If it is not very important, then translate it by another instance of figurative language that covers as much as possible, at least part of the SLT meaning.

4. If the latter is not possible, then translate it by nonfigurative language that covers as much as possible of the SLT meaning.

\section{Literal Translation}

Literal translation is considered by translation theorists as the worst type of translation. Lefevere (1992:102) asserts that:

Literal translation does not find mercy in our eyes, not because they are against the law of translation (as an act of communication) but simply because two languages are never identical in their vocabulary. Ideas are common to the understanding of all men but words and manners of speech are particular to different nations.

Newmark (1988: 76) argues

Literal translation is the first step in translation, and a good translator abandons a literal version only when it is
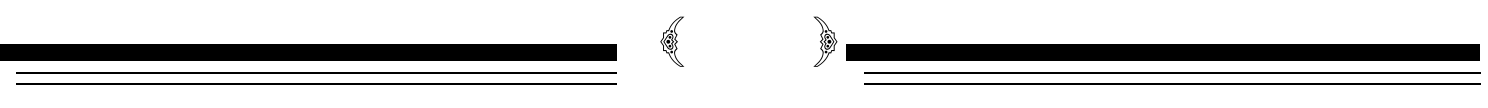
plainly inexact or badly written. A bad translator will always do his best to avoid translating word for word.

Chesterman (1997: 67) believes that this sort of translation is a bad strategy. It makes the translator adopts the source text as closely as possible without pursuing the source language structure.

\section{Translation Strategy}

Translation strategies are techniques used by the translator to solve the problems that may face him/her in translation. Lörscher (1991: 76) defines it as "a potentially conscious procedure for the solution of a problem which an individual is faced with when translating a text segment from one language to another".

Lewandowska-Tomaszczyk et al. (2010: 368) states that

Translating figurative language is not at all an easy task, especially in case there is no equivalent in the Target Language (TL) and when the instance of figurative language is not "standard" for the Source Language (SL).

Leppihalme (1997: 28) defines it as a "means which the translator, within the confines of his/her existing knowledge, considers to be the best in order to reach the goals set by the translation task." He (Ibid) adds that the translator may either consider strategies in abstract terms or try out different possible solutions for the problems at hand because such kind of tools are more likely to lead to successful translations than routine use of one strategy only.

Vinay and Darbelnet (2000:84) explain the strategy that a translator would use to do his/her job:

Generally speaking, translators can choose from two methods of translating, namely direct, or literal translation and oblique translation. In some translation tasks it may be possible to transpose the source language message element by element into the target language, because it is based on either (i) parallel category, in which case we can speak of structural parallelism, or (ii) on parallel concepts, which are the result of metalinguistic parallelisms. But 
translators may also notice gaps, or "lacunae", in the target language (TL) which must be filled by corresponding elements, so that the overall impression is the same for the two messages.

Landers (2001: 91) argues that "a book-length translation is made up of literally thousands of decisions, some as tiny as the choice between a comma and a semicolon, others as momentous as whether to render proper names into the TL or leave them in the SL."

\section{Assessment of Data}

It is worth noting that a good description of the sample and its contents, for the sake of making the assessment, is what Biber (1993: 243) states when saying that:

Typically researchers focus on sample size as the most important consideration in achieving representativeness: how many texts must be included in the corpus, and how many words per text sample. Books on sampling theory, however, emphasize that sample size is not the most important consideration in selecting a representative sample; rather, a thorough definition of the target population and decisions concerning the method of sampling are prior considerations.

In this assessment, it is supposed to find the suitable equivalent in TL text for the SL expressions. But one must put in mind that the concept of equivalence should not be understood as meaning a relationship of sameness because sameness, as Bassnett (1980: 29) refers, "cannot even exist between two TL versions of the same text, let alone between SL and TL version." To a certain extent, it means having the same meaning or effect. In other words, being the receiver of the SL message and the sender of the TL message, the translator should do his/her best to convey all the components of the SL text into the TL text to make the process of communication successful.

Newmark (1988:181) emphasizes the importance of the assessment of translation by saying that it leads to achieve five objectives: 
(1) to improve the level of translation.

(2) to teach translators.

(3) to shed some light on translation at particular times and in particular subject areas.

(4) to help interpreting the work of great writers and translators.

(5) to assess semantic and grammatical differences between the SL and TL.

Reiss (2000:18) considers literary prose as "a tool of artistic creativity, conveying aesthetic values." If these values are not rendered successfully in translation, the result will be a distorted text.

The present assessment includes the two Arabic versions of the English text (The Happy Prince). They are as follows:

$\mathrm{T} 1=$ the text translated by BadriyyaAr-Rawwahi (2003)

$\mathrm{T} 2=$ the text translated by MuzahimHassen Ash-Shammari (1988)

The data for this study is collected from Oscar Wilde's short story 'The Happy Prince' (2003: 7), which was first published in May 1888, and its two Arabic translations.

It is worth mentioning that it is intended, here, to follow Newmark (1988: 189) functional approach in which there will be an assessment of whether or not the translator achieved what he attempted to do and where he fell short.

Besides, he (1991: 163) argues that "the only way to assess the deficiencies of the translation is to examine the linguistic differences between it and the original". That is why the comparative method was adopted here in order to compare two versions of the same text (English as the source-language text and Arabic as the translated text).

These two translations mean that each translator uses different techniques in a way that may lead to defecting the SL text or altering it. By assessing the translations of 'The Happy Prince' into Arabic, one can see the efforts exerted by the translators to do their job.

The assessment will start now by showing the pits and falls of each translation in order to be sure that the translation conveys the message 
adequately, or not. Whenever possible, the researcher will suggest her translation.

High above the city, on a tall column stood the statue of the happy prince. He was gilded all over with thin leaves of fine gold.

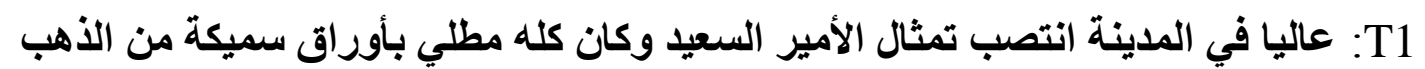

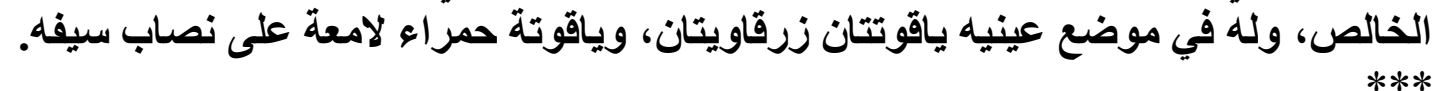

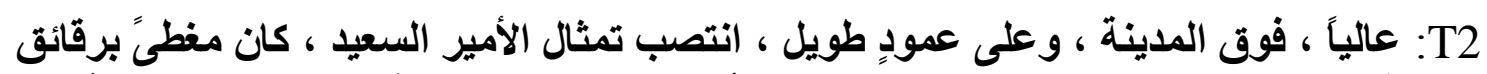

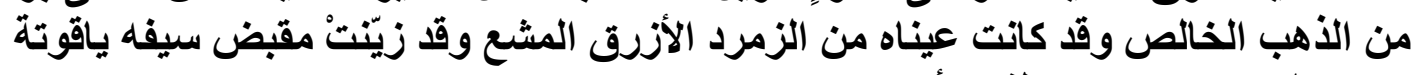
حمراء لها بريق يكاد يخطف الأبصار.

It is quite clear that in T1 the translator did not translate " على عمود طويل " and "فوق المدينة" . Besides, she translated "gilded all over with thin leaves of fine gold" as meaning " مطل بأوراق سميكة من الذهب الخالص ". There is nothing in the TL text referring to thickness. Instead, T2 translated it correctly.

T1 translated 'bright' as " لامعة" while in T2 it was exaggeratingly rendered as" لها بريث يكاد يخطف الأبصار" ". لأبعار"

To gain a reputation for having artistic taste

T1

T2

T1 rendition is not accurate since it mistranslates the word "reputation" as meaning " سمعة " wوة " while T2 chooses the right sense of this lexical item, $"$.

\section{"fearing lest people should think him unpractical."}

T1 قال ذلك خوفاً من أن يعتقد الناس بأن التّمثال ليس عملياً وهو ليس كذلك حقاً

It is clear that $\mathrm{T} 1$ adequately renders the text because she has translated "him" as belonging to the councilor not the statue, while T2 mistranslates it thinking that "him" belongs to the statue and this is illogical because the Wild want us to think that the statue is really practical. 
"asked a sensible mother of her little boy who was crying for the moon"

Translation should not only pay attention to the idea and style of the source language message but also tries to be in line with the target language culture in order not to produce an alien text to the TL receptors. It is clear here that T1 mistranslate the word "moon" and gives a mistaken culture specific word which is absent in the SL text "بيض الانوق " which is not quite understood by most of the ordinary readers, while T2 translation managed to convey the required meaning to the reader.

"said the Charity Children as they came out of the cathedral in their bright scarlet cloaks, and their clean white pinafores."

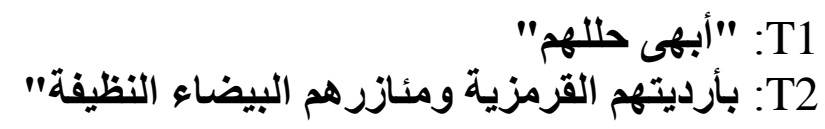

In T1, the whole sentence is left untranslated, contrary to T2 that renders it adequately.

\section{The Reed made him a low bow.}

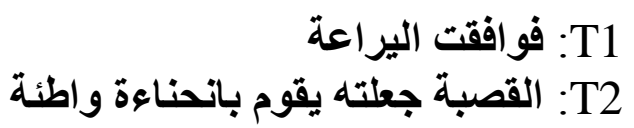

Both translations fell short here to render the intended meaning. T1 mistranslates the word "reed" as meaning " اليراعة " and gives another meaning by saying "فوافقت" ", while it is well known that it means" القصبة ". In T2, meaning is quite altered because of the lack of understanding. It is the reed who bowed to the swallow not the reverse. The sentence can be translated as "انحنت له القصبة بتؤدة ". It is similar in English to the following sentence: She will make him a cup of tea, which if translated literally will sound like: جعلته كوبأ من الثناي but it means: قدمت له كوباً من الثناي

They have set me up here so high that I can see all the ugliness 
T1

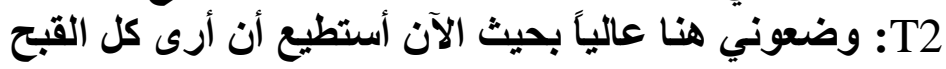

It is evident that the translator in T1 fails to reach the intended meaning by the writer, while T2 grasps it correctly.

Will you not bring her the ruby will you not bring her the ruby out of my sword-hilt?

$$
\begin{aligned}
& \text { T1 ألا لن تحضر لها الياقوتة الحمراء } \\
& \text { T2 :T2: هل للك أن تأخذ لها الياقوتة. }
\end{aligned}
$$

In $\mathrm{T} 1$, the translator did not succeed in getting the intended meaning because she translates literally. The sentence here is a polite request, as is shown in T2. It is possible to say:

$$
\text { هلا أحضرث لها الياقوتة الحمراء }
$$

On a great granite throne sits the god Memnon

$$
\begin{aligned}
& \text { T1 وعلى منزل جرانيت يجلس الإله مأمون. } \\
& \text { T2 على عرش جرانيتي عظيم يجلس الإله آمون. }
\end{aligned}
$$

When looking at this sentence, one can see that $\mathrm{T} 1$ has distorted the theme. It is clear that she does not know that "Memnon" here means" آمون ", the well-known Egyptian god. Moreover, she mistranslated "throne" as meaning " منزل" " عرش" here. She also left the adjective "great" untranslated. T2 chooses the right sense of the lexical item and translates it with an Arabic idiomatic expression

And saw the white faces of starving children looking out listlessly at the black streets

$$
\text { T2: فرأى الأطفال الأبرياء يحدقون بفتورة الثائعين. }
$$

In $\mathrm{T} 1$, the translator distorts the theme which is central in this paragraph. She translated "white faces" as meaning " الأطفال الأبرياء " and left the keyword here "starving" untranslated. In T2, the translator pays attention to this sentence and renders it into a correct Arabic. He grasps the figurative aspect represented by the word "white" which is a metonymy meaning

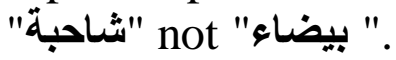


The living always think that gold can make them happy

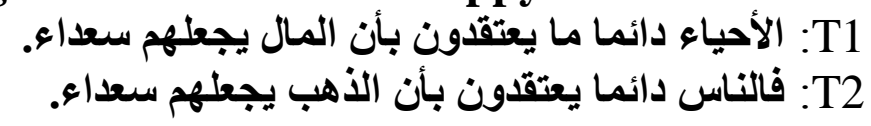

Literal translation in $\mathrm{T} 1$ is poor because it does not render the same feeling of the SL to the TL. It did not give the exact equivalent for the word "living" to be meaning "الأحياء ", while T2 renders adequately as meaning " "المال" " whileT2renders it correctly as

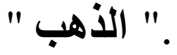

The King of the Mountains of the Moon, who is as black as ebony

$$
\begin{aligned}
& \text { T1 } \\
& \text { T2 ملك جبال القمر الأسود وهو يشبه لون الألعاج نفسه }
\end{aligned}
$$

The lexical item (ebony) is translated as "العاج " which is a mistaken translation that destroyed the intended meaning of the word. It is supposed to be translated as "الأبنوس", which is a black wood. The figurative meaning here is lost in both translations because "العاجن is white while the king is black.

Besides, there are many instances in $\mathrm{T} 2$ in which the translator sticks to the SL text structure and literally renders it in a way which is unacceptable in Arabic. He did not pay attention to the stylistic differences between Arabic and English. There are many examples here, among which are the following:

'Why can't you be like the Happy Prince?' asked a sensible mother of her little boy

$$
\text { لماذا لا تكون مثل الأمير السعيد ؟ سألت الأم الواعية ابنها الصغير. }
$$

I am glad there is someone in the world who is quite happy', muttered a disappointed man

$$
\text { أنا سعيد إن كان يوجد شخص ما سعيد في هذا العالم " غمغم بذلك رجل" فاقد الأمل }
$$

I admit that she is domestic,' he continued, but I love travelling.

\section{Conclusion}

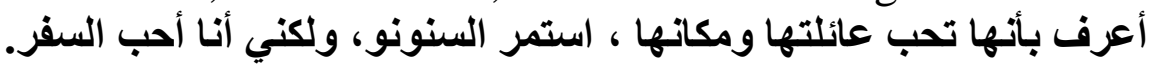


Oscar Wilde is one of the great writes in the nineteen century. He enjoys a very powerful and plain style that can sometimes constitute a hard task to translators. His masterpiece, 'The Happy Prince', is one of the most important short stories.

The present paper has provided some practical guidelines to both translators and students of translation. The difficulty of translating figurative language is supposed to be one of the salient features in translation theories.

After analyzing the SL text, 'The Happy Prince', and the two Arabic translations (namely, T1 and T2) several results have been obtained.

Translation of literary works poses a challenge to translators because of the different structures and cultures between the SL and TL. Translators of literature must have a literary taste and should enjoy a comprehensive knowledge in literature in general, and to the style of the SL author, in particular.

Both translators (in T1 and T2) have performed their translations in a different way; their knowledge of the subject matter is not identical. There are serious mistakes at the level of understanding, but one may say that the translator of $\mathrm{T} 2$ is more efficient in dealing with this literary text than the translator of $\mathrm{T} 1$. He recognizes the intended meanings of the figurative expressions. Yet, there are certain cases in which he fails in his job. Besides, literalness is quite evident in both translations that led to the distortion of meaning. It is well-known that to understand a figurative expression, the context in which it occurs needs to be examined closely.

If the translator cannot understand the meaning of the figurative language in the source text and fails to decipher it correctly, then the result will be a misunderstanding.

Literal translation is generally considered to be the worst possible translation strategy. A figurative expression cannot be translated literally into a second language because it will often be completely misunderstood.

In the theoretical part of the present paper, some light has been shed on the theoretical considerations of both translation and figurative language. Definitions, aims and strategies of translation have been described. Some basic concepts in translation have also been introduced.

\section{Bibliography}

Adams, R. (1973). Proteus: His Lies, His Truth: Discussions of Literary Translation. New York: North Company Inc. 
Ar-Rawwahi, B.(2003). The Happy Prince and Other Tales. Retrieved December 3, 2013 from:

http://ofouq.com/today/modules.php?name=Stories_Archive\&sa=show_m onth\&year $=2003 \&$ month $=08 \&$ month $\_1=\%$ C3\%DB\%D3\%D8\%D3

Ash-Shammari, M. (1988).The Happy Prince and Other Tales. AlJumhuriyya Newspaper. Baghdad: Iraq. (N.D)

Bassnett, S. (1980).Translation studies. London: Methuen

Bell, R.T. (1991). Translation and translating: theory and practice. London: Longman Group.

Belloc, H. (1931). On translation. Oxford: Oxford University Press.

Biber, D. (1993). Representativeness in Corpus Design. New York: Haver Co.

Blanchot, M. (1990).Translation, in: Venuti, Lawrence, The Translator's Invisibility. London: Routledge.

Bressler, C. (1999). Literary Criticism, An introduction to theory and practice. New Jersy: Houghton College.

Brislin, R. W. (1976). Translation: application and research. New York: Gardner Press Inc.

Chesterman, A. (ed.) 1989. Readings in translation theory. Helsinki: Finn Lectura.

Cruse, D. (1986).Lexical Semantics. Cambridge: Cambridge University Press.

Danesi, M \& P. Perron. 1999. Analyzing Cultures: An Introduction and Handbook. Bloomington: Indiana University Press.

Ehrlich, E. (1980). Oxford American Dictionary. Manchester: Oxford University Press.

Finlay, I. F. (1971).Translating. Edinburgh: The English University Press.

Ghzala, H. (2014). Literary Translation: A Literary StylisticBased Perspective. Retrieved March 28 from: http://scik.org/

Glucksberg, S. (2001).Understanding Figurative Language: From Metaphor to Idioms. New York: Oxford University Press.

Hanks, P. (1987) Definitions and Explanations, In: Sinclair, J. (ed.) Looking Up: An account of the COBUILD Project in lexical computing. London and Glasgow: Collins. 
Hopkins, J. (1976) Hermeneutical and Textual Problems of the Complete Treatises of ST. Anselm. Toronto: The Edwin Mellen Press.

Landers, C.E. 2001.Literary translation.A practical guide.Clevedon: Multilingual Matters.

Larson, M.L. 1984. Meaning-based translation.A guide to cross-language equivalence. Lanham: University Press of America.

Lefevere, A. (1992). Translation: History and Culture. London: Routledge. Leppihalme, R. 1997. Culture Bumps. An empirical approach to the translation of Illusions. London: Multilingual Matters.

Lewandowska-Tomaszczyk, B (2010).Meaning in Translation. Frankfurt: Peter Lang GmbH.

Lörscher, W. (1991).Translation performance, translation process and translation strategies.A psycholinguistic investigation.Tubingen: Gunter NarrVerlag.

Newmark, P. (1981). Approaches to translation. Oxford: Pergamon. (1988). A Textbook of Translation. Hertfordshire: Prentice

Hall.

(1998). More Paragraphs on Translation. Philadelphia: Multilingual Matters Ltd: Clevedon.

(1993). Paragraphs on Translation. London: Multilingual Matters.

Nida, E. (1964). Toward a Science of Translating. Leiden: E.J. Brill. (1984). On translation. Beijing: Translation Publishing Corp.Recanati, F. (2004). Literal Meaning. Cambridge: Cambridge University Press.

Reaske, C.(1966).How to analyze poetry. New York: Monarchi Press.

Reimer, B. (1994). Thinking globally about a research agenda for general music. New York: MNEC.

Rojo, A. (2009). Step by Step: A Course in Contrastive Linguistics and Translation. London : Peter Lang.

Steiner, G. (1975). After Babel: Aspects of Language and Translation. London: Oxford University Press.

Thelen, M. (2010).Meaning in Translation. New York: Peter Lang.

Wilde, Oscar (2003). The Happy Prince and Other Tales. London: Fantastica Ltd.

Ullmann, S. (1962).Semantics: An Introduction to the Science of Meaning. Oxford: Blackwell. 
لاوك للفلسفة واللسانيات والعلوم الاجتما عية العدد الخامس عشر السنةالسادسة2014

Vitez, A.(1996) le devoir de traduire.Dépras, Jean-Michel (Ed.). Montpellier: Editions Climats\&Maison.

Wills, W. (1982) The Science of Translation: Problems and Methods. Tubingen: Gunter NarrVerlag. 